\title{
PENINGKATAN KEMAMPUAN MENGENAL KONSEP BILANGAN ANAK USIA 5-6 TAHUN MELALUI MEDIA KARTU ANGKA BERGAMBAR DI TK DHARMA WANITA
}

\author{
Reni Salomen \\ Surel : renisalomen@gmail.com
}

\begin{abstract}
ABSTRAK
Subjek penelitian ini adalah anak usia 5-6 tahun di TK Dharma Wanita Medan, yang berjumlah 15 orang anak yang terdiri dari 8 anak perempuan dan 7 anak laki-laki. Hasil observasi dan refleksi pada siklus I menunjukkan dari hasil penlitian terhadap15 anak, terlihat bahwa anak yang memperoleh kriteria berkembang sesuai harapan sebanyak 2 orang anak (13\%), dan anak yang memperoleh kriteria mulai berkembang sebanyak 13 orang anak (87\%). nilai rata-rata pada siklus I yaitu 54,84. Sedangkan pada siklus II anak yang memiliki tingkat kemampuan konsep bilangan pada kriteria berkembang sangat baik sebanyak 11 orang anak (73\%), sementara itu 4 orang anak (27\%) pada kriteria berkembang sesuai harapan dan tidak ada seorang anakpun yang berada pada kriteria mulai berkembang dan belum berkembang. nilai rata-rata pada siklus 2 yaitu 88,9 .
\end{abstract}

Kata Kunci : Konsep Bilangan, Kartu Angka Bergambar, Kemampuan Anak

\section{PENDAHULUAN}

Belajar bilangan bagi anak usia dini bukan berarti belajar yang menuntut anak untuk mampu berhitung sampai seratus, seribu, atau bahkan menuntut anak untuk memahami operasi matematika yang rumit. Belajar bilangan untuk anak usia dini, lebih kepada pengenalan konsep bilangan dan simbol dari suatu bilangan. Belajar bilangan pada anak usia dini masih dalam proses mengenal bilangan. Mengenal bilangan bukan hanya mengenal bentuk dari bilangan akan tetapi mengenal makna dari bilangan tersebut. Pemahaman konsep bilangan berkembang seiring dengan perkembangan waktu dan kesempatan Jika pengalaman belajar terlalu rumit, anak tidak dapat memahaminya, dan tidak ada peristiwa belajar baru yang muncul. Kemampuan mengenal lambang bilangan merupakan kemampuan anak untuk mengenal simbol-simbol bilangan.Mengenal lambang bilangan penting untuk dikembangkan karena merupakan dasar kemampuan matematika pada anak.Bilangan menurut Sudaryanti (2006: 1) merupakan suatu konsep matematika yang sifatnya abstrak dan termasuk ke dalam unsur yang tidak didefinisikan.Bilangan berkaitan dengan nilai yang mewakili banyaknya suatu benda sedangkan lambang bilangan merupakan notasi tertulis dari sebuah bilangan. Adapun indikator yang berkaitan dengan kemampuan mengenal konsep bilangan yaitu (1) counting (berhitung), (2) one-to-one 
correspondence (koresponden satusatu), (3) quality (kuantitas), (4) comparison (perbandingan) dan (5) recognizing and writing numeral (mengenal dan menulis angka).

Namun kenyataan di lapangan peneliti menyadari bahwa anak belum memiliki kemampuan yang optimal dalam mengenal konsep bilangan, hal ini terlihat dalam membilang (mengenal konsep bilangan dengan benda), menghubungkan/ memasangkan lambang bilangan dengan benda-benda, dan dan mengelompokkan benda menurut warna. Dari 15 orang anak di kelompok B TK Dharma Wanita ditemukan tiga anak perempuan dan tujuh anak laki-laki belum bisa mengenal lambang bilangan dengan baik. Hal ini disebabkan kurang tersedianya bahan-bahan atau alat yang dapat mendorong anak untuk melakukan kegiatan pengenalan konsep bilangan, di samping itu kurang terbukanya kesempatan untuk bermain dan bereksplorasi dengan bebas serta kurangnya peran guru, terutama penggunaan metode yang kurang tepat dalam mendorong ketertarikan anak terhadap pembelajaran konsep bilangan.Anak mengenal lambang bilangan sebatas hafalan, sehingga anak masih terbalik-balik dalam menyebutkan lambang bilangan. Proses membilang anak juga belum tepat yaitu ketidaksesuaian antara pengucapan dengan jumlah benda yang dihitung.
Pada prinsipnya kemampuan mengenal konsep bilangan anak usia dini dapat ditingkatkan asalkan guru mengetahui cara-cara yang tepat. Berbagai cara dapat dicoba oleh guru agar anak mengenal konsep bilangan. Satu diantaranya adalah melalui media kartu angka.Kartu angka dan kartu gambar menurut Heruman (2007: 5) merupakan dua kartu yang saling melengkapi, yang dapat digunakan untuk mengenalkan konsep dan lambang bilangan.Kartu angka bergambar ini dapat dibuat bervariasi dan disesuaikan dengan kebutuhan.Kartu angka bergambar dapat dibuat sendiri oleh pendidik, gambar yang terdapat pada kartu disesuaikan dengan tema yang sedang dikembangkan.Warna-warna yang terdapat pada kartu juga dibuat semenarik mungkin, disesuaikan dengan warna kesukaan anak.Ukuran kartu juga bisa dibuat sesuai kebutuhan.

Bermain kartu angka bergambar dilaksanakan pada kegiatan inti. Adapun langkahlangkah Mengenalkan konsep bilangan untuk anak usia dini melalui kartu angka bergambar menurut Piaget (dalam Slamet Suyanto, 2005: 156) adalah:

a. Mengenalkan bahasa simbol. pada tahap awal ini anak belajar menggunakan kartu gambar. Anak dikenalkan terlebih dahulu satu per satu dengan nama gambar dan jumlah gambar yang terdapat pada kartu bergambar 
yang telah disiapkan. Guru mengangkat satu per satu kartu gambar sambil menghitung jumlah gambar yang terdapat pada kartu gambar tersebut. Anak bersama-sama dibimbing untuk menghitung dan menyebutkan jumlah gambar yang terdapat pada kartu gambar yang diangkat guru.

b. Abstraksi reflektif (reflective abstraction). Pada tahap ini setelah anak mengetahui bahasa simbol dan konsep bilangan dengan benda-benda, kemudian anak dilatih untuk mampu berpikir simbolis. Anak mulai menggunakan jari-jari tangannya untuk menghitung gambar yang terdapat pada kartu gambar sambil berkata "satu", "dua", tiga", dan seterusnya. Pada tahap ini, anak mulai menghubungkan antara jumlah benda dengan bahasa matematis sederhana.

c. Menghubungkan antara pengertian bilangan dengan simbol bilangan. Setelah anak mengetahui makna dari bilangan, kemudian anak dikenalkan pada lambang atau simbol dari bilangan tersebut. Tahap ini bisa dilakukan dengan cara menghubungkan antara kartu angka dengan kartu gambar. Kartu angka 1 dengan kartu gambar yang jumlah gambarnya satu, kartu gambar 2 dengan kartu gambar yang jumlah gambarnya dua, dan seterusnya.
Hal ini dilakukan sampai anak benar-benar mengenal konsep dan lambang bilangan dengan baik.

Berdasarkan latar belakang masalah, dapat dikaji adapun pokok permasalahan yang ingin diangkat dalam penelitian ini adalah: "Apakah media kartu angka bergambar dapat meningkatkan kemampuan konsep bilangan pada anak kelompok B TK Dharma Wanita Tahun Ajaran 2015/2016?"

\section{METODE PENELITIAN}

Penelitian ini dilaksanakan di kelompok B TK Dharma WanitaJl. Pukat No. 4 Medan.Penelitian ini dilaksanakan selama 4 bulan (Maret 2016 s/d Juni 2016), mulai dari persiapan hingga pelaksanaan tindakan

Subjek dalam penelitian tindakan kelas ini adalah anak usia 56 tahun di kelompok BTK Dharma Wanita Medan berjumlah 15 orang, yang terdiri dari 7 anak laki-laki dan 8 anak perempuan. Sedangkan objek penelitian ini adalah meningkatkan kemampuan mengenal konsep bilangan anak usia 5-6 tahun melalui Media Kartu Angka Bergambar di kelompok B TK Dharma Wanita Medan.

Penelitian ini menggunakan desain model Kemmis dan Mc. Taggart (Dewi, 2010:122). Rencana penelitian akan dilakukan dengan 2 siklus, yakni siklus I dan siklus II. Setiap siklus terdiri dari empat tahap, 
yaitu tahap: (1) Perencanaan (planning),(2) Tindakan (acting),(3) Pengamatan (observing) dan (4) Refleksi (reflect).

Pengumpulan data yang digunakan dalam penelitian ini adalah observasi tentang kemampuan mengenal konsep bilangan anak selama kegiatan pembelajaran berlangsung.

Setelah pengumpulan data dilakukan dilanjutkan dengan analisis data digunakan statistik deskriptif. Langkah analisis statistik deskriptif terdiri dari:

$$
P=\frac{f}{n} x 100 \%
$$

Dimana :

$\mathrm{P}=$ Angka persentase klasikal

$\mathrm{f}=$ Jumlah anak yang mengalami perubahan

$\mathrm{n}=$ Jumlah anak seluruhnya.

Setelah rumus untuk mencari perkembangan individu dilakukan, maka selanjutnya adalah mencari perkembangan rata-rata anak dengan menggunakan rumus :

$$
x=\frac{\sum x}{\sum n}(\text { Aqib, 2011:16) }
$$

Keterangan :

$\mathrm{x}=$ Nilai rata-rata

$\sum \mathrm{x}=$ Jumlah semua nilai anak

$\sum \mathrm{n}=$ Jumlah anak

Selanjutnya untuk mengetahui persentase peningkatan kemampuan mengenal konsep bilangan pada anak secara keseluruhan atau klasikal, maka digunakan rumus :

$$
P=\frac{f}{n} \times 100 \%
$$

(Dewi, 2010 :188)

Keterangan :

$\mathrm{P}=$ persentase peningkatan

kemampuan mengenal konsep

bilangan pada anak.

$\mathrm{f}=$ jumlah subjek yang mengalami perubahan.

$\mathrm{n}=$ jumlah subjek keseluruhan

Berdasarkan langkah- langkah di atas maka dibuat tabel interferensi sebagai berikut:

Tabel Kriteria kreativitas Anak Untuk Keseluruhan Indikator

\begin{tabular}{|c|c|}
\hline Prestasi & Keterangan \\
\hline $80 \%-100 \%$ & Berkembang Sangat \\
$60 \%-79 \%$ & Baik (BSB) \\
& Berkembang Sesuai \\
$30 \%-59 \%$ & Harapan (BSH) \\
$10 \%-29 \%$ & Mulai Berkembang \\
& (MB) \\
& Belum Berkembang \\
& (BB) \\
\hline
\end{tabular}

Adaptasi: Aqib (2011:41) dan Permen No. 58 Tahun 2009

\section{HASIL DAN PEMBAHASAN}

Tahap perencanaan ini, peneliti dengan observer membahas teknis pelaksanaan penelitian tindakan kelas. Kegiatan yang dilakukan pada tahap ini adalah sebagai berikut :

a. Menentukan tema yang akan diajarkan sesuai dengan silabus dan kurikulum yaitu Tema Alat Komunikasi Subtema Media Cetak. 
b. Menyusun Rencana Pembelajaran dalam bentuk Rencana Kegiatan harian (RKH)

c. Menyediakan alat-alat dan bahan yang diperlukan untuk media kartu angka bergambar.

d. Merancang alat evaluasi.

e. Membuat lembar observasi tentang konsep bilangan anak.

Pelaksanaan pembelajaran
dilakukan dengan memberikan
tindakan yang menggunakan media
kartu angka bergambardimana
peneliti bertindak langsung sebagai
guru. Kegiatan pemberian tindakan
yang dilakukan merupakan tahap
pengembangan dan pelaksanaan dari
rencana yang telah disusun pada tahap
perencanaan.Kegiatan yang dilakukan
sebagai upaya untuk meningkatkan
kemampuan mengenal konsep
bilangan anak usia 5-6 tahun dengan
menggunakan media kartu angka
bergambar.

Pada tahap ini peneliti melakukan observasi dibantu dengan observer dengan menggunakan lembaran observasi peningkatan kemampuan konsep bilangan anak yang telah disiapkan sebelumnya. Dari observasi yang telah dilakukan diperoleh bahwa:

a. Anak terlihat masih belum dapat menyebutkan bilangan dengan baik.

b. Anak masih terlihat bingung dalam mengerjakan tugasnya

c. Masih ada beberapa anak yang diarahkan dan dibantu oleh guru.
Sementara itu rekaman pembelajaran pada siklus I dapat dilihat pada paparan berikut ini :

Selanjutnya paparan gambaran awal setelah dilakukannya tindakan dan keadaan pada siklus I yang diperoleh dari hasil observasi dapat dilihat pada tabel di bawah ini:

Tabel Rekapitulasi Peningkatan Kemampuan Konsep Bilangan Anak pada Siklus I

\begin{tabular}{|l|c|c|c|}
\hline Nilai & $\begin{array}{c}\text { Jumlah } \\
\text { Anak }\end{array}$ & $\begin{array}{c}\text { Persentase } \\
\text { Jumlah } \\
\text { Siswa }\end{array}$ & Keterangan \\
\hline $80-100 \%$ & 0 & 0 & BSB \\
\hline $60-79 \%$ & 2 & 13 & BSH \\
\hline $30-59 \%$ & 13 & 87 & MB \\
\hline $10-29 \%$ & 0 & 0 & BB \\
\hline
\end{tabular}

Dari pengamatan yang telah dilakukan, terlihat bahwa kemampuan konsep bilangan anak usia 5-6 tahun di TK Dharma Wanita masih tergolong belum baik semua. Oleh karena itu, peneliti akan melakukan perbaikan-perbaikan yang nantinya diharapkan dapat meningkatkan kemampuan konsep bilangan anak usia 5-6 tahun menjadi lebih baik.

Adapun keberhasilan dan kegagalan yang terjadi pada siklus I adalah sebagai berikut:

a. Pada kegiatan awal, anak memiliki respon yang baik terhadap tema yang dijelaskan oleh peneliti (guru).

b. Masih ada beberapa anak yang belum memahami dan mengerjakan tugas.

c. Hasil belajar dengan Tema alat Komunikasi Subtema Media Cetak pada siklus I masih belum 
optimal, hanya $13 \%$ anak yang mencapai kriteria berkembang sesuai harapan, sementara $87 \%$ masih pada kriteria mulai berkembang.

d. Proses kegiatan media kartu angka bergambar masih belum kondusif.

Penerapan langkah-langkah media kartu angka bergambar yang dilaksanakan guru sudah cukup baik ( 75 ) tetapi belum maksimal.

\section{Untuk}

memperbaiki

kelemahan dan mempertahankan keberhasilan yang telah dicapai pada Siklus I, maka pelaksanaan pada Siklus II dapat dibuat perencanaan sebagai berikut :

a. Peneliti (guru) membuat Rencana Kegiatan Harian (RKH) dengan Tema alat Komunikasi Subtema Media Elektronik dan menggunakan media yang bervariasi agar anak lebih tertarik dan bersemangat dalam mengerjakan tugas yang diberikan.

b. Mempersiapkan lembar observasi, yang berisikan pencapaian indikator-indikator kemampuan mengenal konsep bilangan anak usia 5-6 tahun.

c. Memberikan motivasi kepada anak agar lebih aktif lagi dalam pembelajaran dengan cara anak dapat menikmati hasil dari kerja mereka.

d. Lebih intensif membimbing anak yang mengalami kesulitan. e. Memberikan pengakuan dan pujian kepada anak.

Sebelum

kegiatan pembelajaran berlangsung dengan menggunakan media kartu angka, peneliti mempersiapkan diri agar penelitian berlangsung lebih baik. Pada tahap ini peneliti melaksanakan kegiatan yang telah disusun pada RKH.

Dari observasi yang telah dilakukan, maka diperoleh beberapa perihal yang dilakukan anak pada saat kegiatan pembelajaran berlangsung, antara lain:

a. Anak dapat merespon dengan baik apa yang disampaikan peneliti.ini terlihat ketika anak sudah mengenali lambang bilangan yang ditunjuk untuk disebutkan atau dituliskan. Hal yang sama juga terlihat pada pertemuan kedua Siklus II.

b. Anak terlihat semangat dalam menyelesaikan tugas di dalam kelompoknya.

c. Anak sudah mengenali dapat menyelesaikan tugas dengan baik, terlihat dari hasil kerja mereka yang memuaskan.

Selanjutnya untuk melihat peningkatan kemampuan konsep bilangan anak setelah dilakukan tindakan pada siklus II, maka peneliti mengolah data berdasarkan indikatorindikator yang di dapat dari tabel lembar observasi anak pada Siklus II. 
Tabel Rekapitulasi Peningkatan Kemampuan Konsep Bilangan Anak pada Siklus II

\begin{tabular}{|c|c|c|c|}
\hline $\begin{array}{c}\text { Rata-Rata } \\
\text { Nilai }\end{array}$ & $\begin{array}{c}\text { Jumlah } \\
\text { Anak }\end{array}$ & $\begin{array}{c}\text { Persentase } \\
\text { Jumlah } \\
\text { Siswa }\end{array}$ & Keterangan \\
\hline $80-100 \%$ & 11 & $73 \%$ & BSB \\
\hline $60-79 \%$ & 4 & $27 \%$ & BSH \\
\hline $30-59 \%$ & 0 & 0 & MB \\
\hline $10-29 \%$ & 0 & 0 & BB \\
\hline
\end{tabular}

Dari tabel di atas dapat dilihat bahwa anak yang memiliki tingkat kemampuan konsep bilangan pada kriteria berkembang sangat baik sebanyak 11 orang anak (73\%), sementara itu 4 orang anak (27\%) pada kriteria berkembang sesuai harapan dan tidak ada seorang anakpun yang berada pada kriteria mulai berkembang dan belum berkembang.

Setelah mengamati hasil analisis data dari Siklus II, anak usia 5-6 tahun di TK Dharma Wanita dapat dikatakan mengalami peningkatan kemampuan konsep bilangan. Hal ini terlihat dari data observasi pada siklus I dengan nilai rata-rata 54,84 dan data pada siklus II dengan nilai rata-rata 88,9 . Oleh karena itu peneliti tidak perlu melakukan kegiatan pembelajaran dengan menggunakan media kartu angka bergambar pada siklus berikutnya.

Pada siklus I dilakukan penelitian dengan media kartu angka bergambar, dimana kegiatan lebih banyak didominasi oleh guru serta media yang disediakan sudah sering dilihat maupun digunakan oleh anak sehingga anak kurang tertarik dalam proses pembelajaran. Penelitian ini langsung melibatkan anak Kelompok BTK Dharma Wanita. Media kartu angka bergambar ini mengarahkan agar kemampuan konsep bilangan anak usia 5-6 tahun meningkat dengan baik dan sesuai dengan usianya. Hasil dari Siklus I diperoleh kemampuan konsep bilangan anak masih belum maksimal. Dari tabel 4.1 dapat dilihat bahwa pada siklus I di peroleh nilai rata-rata anak 54,84, yang berarti rata-rata peningkatan kemampuan mengenal konsep bilangan anak pada kriteria mulai berkembang.Pada table 4.2, dari 15 anakterlihat bahwa anak yang memperoleh kriteria berkembang sesuai harapan sebanyak 2 orang anak (13\%), dan anak yang memperoleh kriteria mulai berkembang sebanyak 13 orang anak $(87 \%)$. nilai rata-rata pada siklus I yaitu 54,84 .

Pada siklus II dilaksanakan penelitian dengan menyediakan media yang lebih beragam dan nyata agar anak lebih tertarik untuk memperoleh kemampuan konsep bilangan anak yang maksimal. Pada siklus II terjadi peningkatan yang signifikan, berdasarkan tabel 4.3 dapat dilihat bahwa setelah dilakukan tindakan pada Siklus II diperoleh nilai rata-rata anak 88,9, yang berarti rata-rata peningkatan kemampuan konsep bilangan anak pada kriteria berkembang sangat baik. Dari tabel 4.4 dapat dilihat bahwa anak yang memiliki tingkat kemampuan konsep bilangan pada kriteria berkembang 
sangat baik sebanyak 11 orang anak (73\%), sementara itu 4 orang anak (27\%) pada kriteria berkembang sesuai harapan dan tidak ada seorang anakpun yang berada pada kriteria mulai berkembang dan belum berkembang.

Dari penelitian yang dilakukan pada siklus I dan siklus II didapat bahwa nilai rata-rata kemampuan konsep bilangan anak mengalami peningkatan sebesar 34,06. Penggunaan media kartu angka bergambar memperlihatkan bahwa lebih efektif digunakan dalam meningkatkan kemampuan mengenal konsep bilangan anak usia 5-6 tahun .

Dengan demikian pertanyaan penelitian dapat terjawab bahwa media kartu angkabergambar merupakan salah satu upaya yang dapat meningkatkan kemampuan mengenal konsep bilangan.

\section{SIMPULAN}

Berdasarkan hasil penelitian dan analisis data, dapat disimpulkan sebagai berikut :

a. Media kartu angkabergambar pada pembelajaran dapat meningkatkan kemampuan mengenal konsep bilangan anak usia 5-6 tahun di TK Dharma Wanita Medan. Peningkatan kemampuan konsep bilangan anak pada siklus I diperoleh kemampuan konsep bilangan anak masih rendah. Dari 15 anak, terlihat bahwa anak yang memperoleh kriteria berkembang sesuai harapan sebanyak 2 orang anak (13\%), dan anak yang memperoleh kriteria mulai berkembang sebanyak 13 orang anak $(87 \%)$. nilai rata-rata pada siklus I yaitu 54,84. Pada siklus ini kemampuan klasikal belum tercapai secara optimal.

b. Pada siklus II terjadi perkembangan yang signifikan, anak yang memiliki tingkat kemampuan konsep bilangan pada kriteria berkembang sangat baik sebanyak 11 orang anak (73\%), sementara itu 4 orang anak $(27 \%)$ pada kriteria berkembang sesuai harapan dan tidak ada seorang anakpun yang berada pada kriteria mulai berkembang dan belum berkembang. nilai rata-rata pada siklus 2 yaitu 88,9 .

\section{DAFTAR RUJUKAN}

Aqib, Zainal, dkk. 2011. Penelitian

Tindakan Kelas Untuk Guru

$S D$, SLB, dan TK. Bandung: Yrama Widia.

Dewi, $\quad 2010$. Profesionalisasi Guru

Melakukan Penelitian Tindakan

Kelas. Medan. Pasca Sarjana Unimed.

Heruman. 2007. Model Pembelajaran Matematika. Bandung: PT. Remaja Rosdakarya. 
Reni Salomen: Peningkatan Kemampuan ...

Kemendiknas. 2009. Permen Nomor 58 tahun 2009 Standar Perkembangan Anak. Jakarta.

Reni, Salomen. 2016. Efektivitas Media Kartu Angka Bergambar Dalam Meningkatkan Kemampuan Mengenal Konsep Bilangan Anak Usia 5-6 Tahun Di TK Dharma Wanita Tahun Ajaran 2015/2016. Medan.

Sudaryanti. 2006. Pengenalan Matematika Anak Usia Dini. Yogyakarta: UNY Press.

Suyanto, Slamet. 2005. Konsep Dasar Pendidikan Anak Usia Dini. Jakata: Depdiknas. 
